\title{
PENGARUH ENGAGING LEADERSHIP TERHADAP KOMITMEN ORGANISASI, PERILAKU KEWARGAAN ORGANISASIONAL, DAN KETERIKATAN KERJA DI PT.XYZ
}

\author{
Valen \\ Program Studi Magister Manajemen Universitas Tarumanagara \\ hellovalenlie@gmail.com \\ Rostiana \\ Program Studi Magister Manajemen Universitas Tarumanagara \\ Masuk : 05-06-2020, revisi : 24-06-2020 diterima untuk diterbitkan : 24-06-2020
}

\begin{abstract}
This study aims to examine the effect of engaging leadership on organizational commitment, organizational citizenship behavior and work engagement. The population of this study was 200 employees and got 157 participants in the end that valid to proceed the answer. The result is we found engaging leadership have effect on work engagement. However, we did not find the effect of engaging leadership toward organizational commitment and organizational citizenship behavior.
\end{abstract}

Abstrak: Penelitian ini bertujuan untuk menguji pengaruh engaging leadership terhadap komitmen organisasi, perilaku kewargaan organisasional dan keterikatan kerja. Populasi penelitian ini adalah 200 karyawan dan sebanyak 157 target sampel didapatkan dan dapat diolah datanya karena telah lengkap menjawab pertanyaan di kuesioner. Hasil dari penelitian ini menemukan adanya pengaruh engaging leadership terhadap keterikatan kerja. Namun tidak ditemukan pengaruh engaging leadership terhadap komitmen organisasi dan perilaku kewargaan organisasional.

Keywords: Engaging Leadership, Organizational Commitment, Organizational Citizenship Behavior, Work Engagement

\section{PENDAHULUAN}

Saat ini perubahan sosial ekonomi dan teknologi sedang terjadi ditengah era globalisasi. Munculnya percepatan teknologi menciptakan beberapa perubahan pada karakteristik dan orientasi bisnis pengusaha. Oleh karena itu, organisasi membutuhkan kepemimpinan yang mampu mencerahkan dan responsif terhadap perubahan yang terjadi (Malik, Saleem \& Naeem, 2016). Kepemimpinan didefinisikan sebagai kemampuan untuk mempengaruhi orang lain dengan tujuan menyelesaikan masalah. Dalam konteks organisasi, kepemimpinan dibutuhkan untuk mempengaruhi perilaku dan komunikasi antara karyawan dan atasan sehinga tujuan organisasi dapat tercapai (Lian \& Tui, 2012). Menurut Mintzberg, Collins, dan Tosi (dikutip dalam Alimo-Metcalfe, Alban-Metcalfe, Bradley \& Mariathasa, \& Samele, 2008) saat ini kita hidup dalam 'Post-heroic' era, yaitu era yang ditandai oleh gaya kepemimpinan yang jauh lebih inklusif dan lekat. Model kepemimpinan tersebut direfleksikan sebagai engaging leadership, yaitu gaya kepemimpinan yang menghargai orang lain dan peduli terhadap perkembangan serta kesejahteraan karyawannya. Engaging leadership diprediksi dapat mempengaruhi sikap karyawan agar sejalan dengan harapan organisasi. Sikap karyawan ini yang ingin diuji oleh peneliti, mencakup komitmen organisais, perilaku kewargaan organisasional dan keterikatan kerja. Schaufeli (2015) menemukan bahwa engaging leadership memiliki pengaruh terhadap keterikatan kerja. Podsakoff, MacKenzie, Moorman dan Fetter (1990) kepemimpinan dapat mempengaruhi munculnya organizational citizenship behaviour (selanjutkan akan disebut sebagai perilaku kewargaan organisasional atau PKO). Perilaku kewargaan organisaisonal 
adalah perilaku sukarela yang dilakukan tanpa paksaan dan tanpa harapan hadiah dari organisasi. Selain keterikan kerja dan perilaku kewargaan organisasional beberapa dekade terakhir juga menemukan bahwa kepemimpinan memiliki hubungan positif dengan komitmen organisasi bahkan dianggap sebagai salah satu prediktor yang paling kuat untuk menciptakan hadirnya komitmen organisasi. Menurut Allen dan Meyer (1991) komitmen organisasi adalah kelekatan emosional antara karyawan dengan perusahaan yang mengakibatkan rendahnya keinginan karyawan untuk meninggalkan perusahaan dan mendorong munculnya perilaku yang diharapkan oleh perusahaan.

\section{METODE PENELITIAN}

Pendekatan yang digunakan dalam penelitian ini adalah pendekatan kuantitatif. Penelitian ini merupakan jenis penelitian kuantitatif dengan bentuk noneksperimental. Alasan peneliti menggunakan pendekatan ini adalah untuk menghilangkan subyektivitas dalam penelitian. Pengambilan data dengan pendekatan kuantitatif noneksperimental dilakukan satu kali (ex post facto). Penelitian ini merupakan penelitian yang menggunakan pengujian hipotesis, oleh karena itu jenis penelitian yang digunakan adalah causal research. Causal research bertujuan untuk mengetahui variabel yang memberi pengaruh (variabe independen) dan variabel yang terpengaruh (variabel dependen) dan juga untuk mengetahui hubungan antara variabel-variabel (Rangkuti, 2007). Karakteristik partisipan penelitian ini, yaitu (a) karyawan tetap PT. XYZ, (b) memiliki jenjang sekolah minimal SMA, (c) bekerja minimal satu tahun. Alasan peneliti menggunakan partisipan karyawan tetap yang telah bekerja minimal satu tahun disebabkan karyawan sudah beradaptasi dengan kondisi lingkungan kerja dan pekerjaannya. Pada penelitian ini tidak ada batasan jenis kelamin, jabatan, status pernikahan, dan agama. Populasi penelitian ini adalah 200 karyawan, namun setelah di screening terhadap 157 kuesioner yang valid untuk diuji lebih lanjut. Kuesioner yang digunakan antara lain skala komitmen organisasi yang dikembangkan oleh Allen dan Meyer, skala perilaku kewargaan organisasional yang dikembangkan oleh Podsakoff, MacKenzie, Moorman dan Fetter, skala keterikatan kerja yang dikembangkan oleh Schaufeli, dan skala engaging leadership yang dikembangkan oleh Schaufeli. Hasil pengumpulan kuesioner yang telah dibagikan kepada responden, kemudian dianalisis dengan metode lisrel. Pengujian dengan metode Lisrel bertujuan untuk mengetahui bagaimana pengaruh langsung (direct effect) antara variabel independen dengan variabel dependen. Peneliti menggunakan program Lisrel 8.8 untuk melakukan uji measurement model dan uji structural model.

\section{HASIL PENELITIAN}

Hasil Pengolahan data menggunkan Lisrel dapat dilihat pada tabel 1. Berdasarkan tabel 1 terdapat 2 (dua) hipotesis yang ditolak dan 1 (satu) hipotesis yang diterima.

\section{Tabel 1}

Hasil Pengujian Hipotesis Model Penelitian

\begin{tabular}{|c|c|c|c|c|}
\hline Hipotesis & Pernyataan Hipotesis & $\begin{array}{l}\text { Nilai } \\
\text { T- } \\
\text { Value }\end{array}$ & $\begin{array}{ll}\text { Nilai } & \text { T- } \\
\text { Value } & \end{array}$ & Keterangan \\
\hline $\mathrm{H} 1$ & $\begin{array}{l}\text { Engaging leadership memiliki pengaruh } \\
\text { pada komitment organisasi }\end{array}$ & 0.75 & $0.75<1.96$ & $\begin{array}{l}\text { Data Tidak mendukung } \\
\text { hipotesis }\left(\mathrm{H}_{1} \text { ditolak }\right)\end{array}$ \\
\hline $\mathrm{H} 2$ & $\begin{array}{l}\text { Engaging leadership memiliki pengaruh } \\
\text { pada perilaku kewargaan organisasional }\end{array}$ & -.0 .42 & $\begin{array}{l}-0.42 \\
1.96\end{array}$ & $\begin{array}{l}\text { Data tidak mendukung } \\
\text { hipotesis }\left(\mathrm{H}_{2} \text { ditolak }\right)\end{array}$ \\
\hline H3 & $\begin{array}{l}\text { Engaging leadership memiliki pengaruh } \\
\text { pada keterikatan kerja }\end{array}$ & 4.39 & $4.39>1.96$ & $\begin{array}{l}\text { Data mendukung hipotesis } \\
\left(\mathrm{H}_{3} \text { diterima }\right)\end{array}$ \\
\hline
\end{tabular}

Pada hasil pengujian hipotesis pertama $\left(\mathrm{H}_{1}\right)$, ditemukan bahwa hasil analisis tidak mendukung hipotesis $\mathrm{H}_{1}$ yaitu engaging leadership tidak memiliki pengaruh terhadap komitmen organisasi, karena nilai $t$ - value sebesar $0.75<1.96$. Hal ini berarti pada saat Engaging leadership mengalami perubahan, maka tidak akan menyebabkan perubahan signifikan terhadap komitmen organisasi. 
Pada hasil pengujian hipotesis kedua (H2), ditemukan bahwa hasil analisis tidak mendukung hipotesis $\mathrm{H} 2$, yaitu engaging leadership tidak memiliki pengaruh terhadap perilaku kewargaan organisasional, karena nilai $t$-value sebesar $-0.42<1.96$. Hal ini berarti pada saat engaging leadership mengalami perubahan, maka tidak akan menyebabkan perubahan signifikan pada perilaku kewargaan organisasional.

Pada hasil pengujian hipotesis ketiga (H3), ditemukan bahwa hasil analisis mendukung hipotesis H3, yaitu engaging leadership memiliki pengaruh terhadap keterikatan kerja, karena nilai $t$-value sebesar $4.39>1.96$. Dari hasil pengujian ini menunjukkan bahwa engaging leadership berpengaruh positif dan signifikan terhadap keterikatan kerja. Hal ini berarti pada saat engaging leadership mengalami perubahan maka akan menyebabkan perubahan signifikan terhadap keterikatan kerja. Penjelasan lebih lanjut dapat dilihat pada gambar 1 dan 2

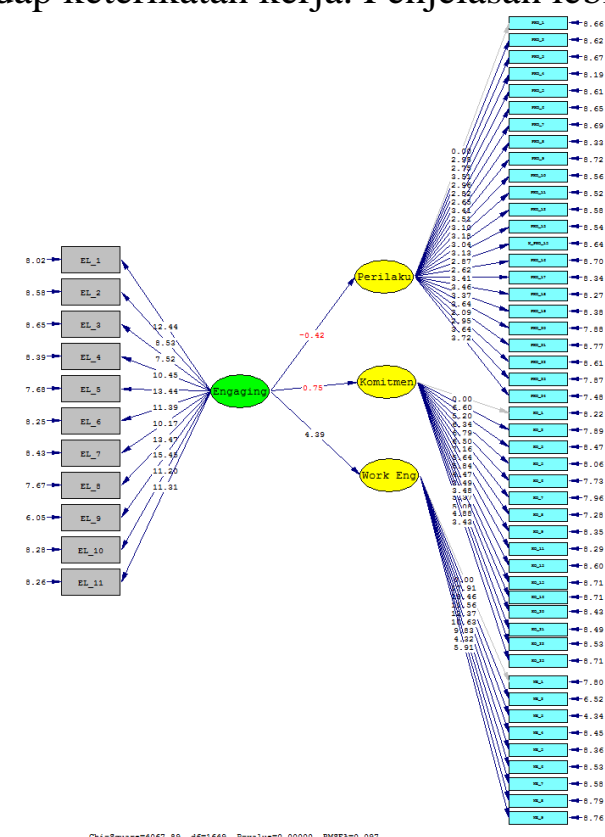

Gambar 1 Hasil Uji Hipotesis 1

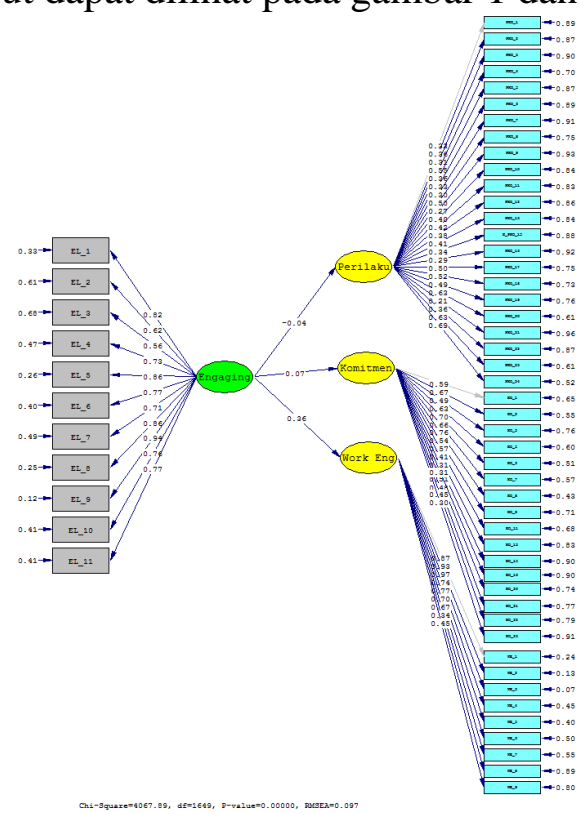

Gambar 2 Hasil Uji Hipotesis 2

\section{KESIMPULAN DAN SARAN}

Dari hasil pengujian diketahui bahwa engaging leadership memiliki pengaruh terhadap keterikatan kerja. Hal ini sesuai dengan penelitian Schaufeli (2015) yang mengatakan bahwa tipe engaging leadership dapat mendorong munculnya keterikatan kerja pada karyawan. Namun tidak ditemukan pengaruh engaging leadership terhadap komitmen organisasi dan perilaku kewargaan organisasional. Hal ini bisa dikarenakan karena komitmen organisasi seorang karyawan dipengaruhi oleh banyak faktor, terutama faktor personal. Kesalahan dalam memilih pekerjaan, masalah keluarga hingga kesehatan bisa mempengaruhi komitmen seseorang terhadap organisasi tempatnya bekerja. Menurut James dan James (dikutip oleh Organ, Podsakoff \& MacKenzie, 2006) mengemukakan bahwa emosional kognitif dan evaluasi lingkungan kerja menjadi faktor bagi individu untuk memunculkan perilaku kewargaan organisasional. Sikap kerja yang mendorong munculnya PKO dalam beberapa penelitian sebelumnya dikatakan disebabkan oleh kepribadian individu tersebut. Kepribadian merefleksikan perilaku yang muncul dalam frekuensi cukup sering di situasi dengan tidak adanya insentif, tekanan, ancaman, atau norma untuk bertindak (Organ, Podsakoff \& MacKenzie, 2006). Hal yang menarik adalah ditemukan level perilaku kewargaan organisasional subyek penelitian ini tergolong cukup tinggi, yaitu rata-rata 3.04. Hal ini bisa menjadi bahan penelitian selanjutnya untuk melihat faktor apa yang bisa mempengaruhi perilaku kewargaan organisasional di PT.XYZ. penelitian selanjutnya untuk meneliti variabel keterikatan kerja sebagai moderator pengaruh engaging leadership terhadap komitmen 
organisasi dan perilaku kewargaan organisasional. Penelitian selanjutnya juga bisa meneliti pengaruh faktor internal seperti kepribadian terhadap engaging leadership, sehingga literasi variabel engaging leadership bisa semakin bertambah. Selain itu juga bisa meneliti faktor penyebab perilaku kewargaan organisasional yang belum ditemukan dalam penelitian ini.

\section{REFERENSI}

Filsafati, A. I., \& Ratnaningsih, I. Z. (2016). Hubungan antara subjective well-being dengan organizational citizenship behavior pada karyawan PT. Jateng Sinar Agung Sentosa Jawa Tengah \& DIY. Empati, 5(4), 757-760.

Huok, A. C. H. (2017). Work Engagement: Evolution of the Concept and A New Inventory. Psychological Thought, 10(2), 262-287.

Khaleh, L.A.B.C., \& Naji, S. (2016). The relationship between organizational commitment components and organizational citizenship behavior in nursing staff. International journal of medical research \& health science, 5(5), 173-175.

Mahoney, A. C. (2015). Commitment and employee development: comparing generations $X$ and $Y$. (Thesis diterbitkan). San Jose State University, California.

Mehrab, J., Alemzadeh, M., Jadidi, M., \& Mahdevar, N. (2013). Explaining the relationship between organizational commitment and dimensions of organizational citizenship behavior. IJCRB, 5(8), 126-130.

Muhammad, M. S., \& Anisa, H. (2012). Relationship between organizational commitment and organizational citizenship behavior. The IUP Journal of Organizational Behavior, 11(3), 7-8.

Naiemah, S. U., Aris, A. Z. Z, Karim, K. M., Samah, I. H. S., Sa'aban, S., \& Suhana, A. M. (2017). Relationship between organizational commitment, OCB, organizational justice and turnover intention: Evidence from educational institution in Malaysia. Integrative business and economic research, 6(2), 69-74.

Oriz, M.Z., Rosario, E., Marquez, E., \& Gruneiro, P.C. (2014). Relationship between organizational commitment and organizational citizenship behavior in a sample of private banking employees. Emerald, 35(1/2), 91-102.

Pourgaz, A.W., Naruei, A.G., \& Jenaabadi, H. (2015). Examining the relationship of organizational citizenship behavior with organizational commitment and equity perception of secondary school administrators. Scientific research publishing, 6, 800802.

Prathiba, S., \& Balakrishnan. (2017). Organizational citizenship behavior of Gen Y's at workplace with special reference to private sector banks in Chennai. BVIMSR, 9(1), 6668.

Schaufeli, W. B. (2015). Engaging Leadership in the Job Demands-Resources Model. Emerald Insight, 20(5), 446-463.

Schaufeli, W. B. (2012). Work Engagement. What Do We Know and Where to Go? Work Engagement in Everyday Life, Business and Academia. Journal of Applied Psychology, 14(1), 3-10.

Shragay, D., \& Tziner, A. (2011). The generational effect on the relationship between job involvement, work satisfaction, and organizational citizenship behavior. Colegio official de psicologos de Madrid, 27(2), 143-146.

Williams, P., Kern, M. L., \& Waters, L. (2015). A longitudinal examination of the association between psychological capital, perception of organizational virtues and work happiness in school staff. Psych well-being, 5, 1-3. doi: 10.1186/s13612-015-0032-0.

Yurcu, G., Colakoglu, U., \& Atay, H. (2015). The effect of organizational citizenship behavior on subjective well-being. International Journal of Business and Social Science, 6(8), 120-121. 